\title{
International Trade in Aquatic Animals and Aquatic Animal Health: What Lessons Have We Learned So Far in Managing the Risks?
}

\author{
Melba G. Bondad-Reantaso*, Audun Lem and Rohana P. Subasinghe \\ Department of Fisheries and Aquaculture, Food and Agriculture Organization of the United \\ Nations (FAO), Viale delle Terme di Caracalla 00153 Rome, Italy
}

\begin{abstract}
Aquatic animals and their products are among the most widely traded commodities where some 40 percent of global production enters the international market. The international trade in aquatic animals and their products are carried out for various reasons. A number of aquatic animal health threats and risks in the international movement of live aquatic animals include the emergence of new pathogens due to the rapid development of aquaculture, limitations in control options for aquatic animal diseases, occurrence of multi-factorial disease syndromes, frequent sub-clinical infections in aquatic animals, undomesticated status of aquatic animals and little information available on biological requirements and health status, etc. In addition to these, because of the volume of live aquatic animals traded internationally, the diversity of species being moved, the many known and potential pathogens that infect aquatic species, the lack and/or weak enforcement of regulations and in other cases, lack of sector regulations itself- it has been a difficult task to find ways that will reduce the risks of spreading transboundary pathogens. This paper looks at the lessons learned and future challenges in managing the risks of disease incursion associated with the international trade of live aquatic animals.
\end{abstract}

Key words: international trade, aquaculture, aquatic animal health, biosecurity, risk analysis, transboundary aquatic animal diseases (TAADs)

Aquaculture, the farming of aquatic organisms including fish, molluscs, crustaceans and aquatic plants, has been the fastest growing source of food and agricultural income worldwide for the past 20 years. The sector grew tremendously during the last half-century, from a production of less than a million tonnes in the early 1950s, to over 50 million tonnes in 2006, valued at USD 78.8 billion (FAO, 2007a). While production from the capture fishery ceased to grow around the mid-1980s, the aquaculture sector has maintained an average annual growth rate of 8.7 percent worldwide since 1970 . According to the Food and Agriculture Organization (FAO) statistics, nearly 50 percent of the world food fish is now produced by aquaculture. It is foreseen that aquaculture will be the major contributor to food fish supply to meet the increasing demand in the decades to come.

However, like other farming systems, aquaculture is constrained with transboundary aquatic animal diseases (TAADs) ${ }^{1}$ (Bondad-Reantaso, 2004; Baldock,

\footnotetext{
* Corresponding author

E-mail: Melba.Reantaso@fao.org

This paper was presented in " 5 th International Symposium of the Japanese Society for Fish Pathology" held in Tokyo (October 18-19, 2008).

1 TAADs, similar to Transboundary Animal Diseases (TADs) are diseases that are highly contagious or transmissible, hav-
}

2002) and other biosecurity concerns (e.g. lack of sanitary control, use of antibiotics, etc.) which seriously threaten its great potential to effectively contribute to food security, nutritional well-being, economic development and poverty reduction.

The expansion and diversification of the sector, alongside with globalization and increased international trade and movement of fish and fishery products across national borders have led to a rise in incidences of serious mortalities and disease outbreaks stemming from incursions of exotic pathogens. Additional factors contributing to the current disease situation in aquaculture include the following: introduction of new species for aquaculture development; expansion of the ornamental fish trade; enhancement of marine and coastal areas through stocking of aquatic animals raised in hatcheries; unanticipated interactions between cultured and wild populations of aquatic animals; poor or lack of effective biosecurity measures; slow awareness on emerging diseases; misunderstanding and misuse of specific pathogen free (SPF) stocks; climate change; and other human-mediated movements of aquaculture commodities (Bondad-Reantaso et al., 2005). Thus, the disease situation in aquaculture is constantly evolving also

ing the potential for very rapid spread irrespective of national borders and causing serious socio-economic and possibly health consequences. 
due to external factors such as changes in the international trading environment - and is affected by globalization, increasing aquaculture production and microbial adaptation.

Many examples exist demonstrating the devastating impacts of TAADs (e.g. direct production losses, increased operating costs, restrictions on trade and impacts on biodiversity, threat to livelihood, food security and nutritional well-being of fish farming communities) such as the epizootic ulcerative syndrome (EUS) in freshwater and brackishwater finfish during the 1980s and the 1990s, which had, in 2006, recently expanded its range to the African region; viral nervous necrosis (VNN) or viral encephalopathy and retinopathy (VER) in marine finfish since the 1990s; penaeid acute viremia (PAV) or white spot disease (WSD) of penaeid shrimp from the early 1990s and which had affected almost all shrimp producing regions in the world; koi herpesvirus infection affecting the important food fish common carp Cyprinus carpio and the high value ornamental koi carp since the 1970s until present and recently, expanding its distribution, beginning 2000, to the Asian region. Infectious salmon anaemia (ISA), a viral infection of salmon, has negatively impacted Chile's salmon industry threatening the employment of the sector's 55,000 workers. ISA is also present in other salmon producing countries such as Canada, Norway, United Kingdom and the United States of America (USA). On a global scale, losses due to shrimp diseases are estimated to be around USD 3,019 million (Israngkura and Sae-Hae, 2002).

This paper presents a discussion on international trade in aquatic animals and aquatic animal health what lessons have we learned so far in managing the risks.

\section{World fish production and world fish trade: challenges as pathway for the spread of aquatic animal diseases}

Although most international trade in aquatic animals are carried out for the food fish market, some trade takes place for other purposes. Both aquaculture development as well as ongoing aquaculture operations, the market for baitfish and the sport fisheries sector are to some extent dependent upon imports. The ornamental fish sector is also one for which international trade is important. Likewise, some live aquatic animals as well as certain fish and fishery products have applications in animal feed, in medicine, in health products and as basis for research and are traded internationally for this purpose. However, an increase in trade will also increase the potential of facilitating new mechanisms by which pathogens and diseases may be introduced and spread to new areas together with host movement. It is therefore important that trade is car- ried out according to existing rules and regulations, in respect of import requirements as well as international and national guidelines for responsible fish trade.

Capture fisheries increased for many years as capacity was expanded and new technology adopted by the world's fishermen, but overall catch levels have now stagnated at around 90-95 million tonnes, although there are yearly fluctuations. Growth in total supply is therefore now from aquaculture alone. Aquaculture production has in fact grown tremendously over the last two-three decades now exceeding 50 million tonnes or about $1 / 3$ of total global food fish supply, but almost 50 percent of fish produced for human consumption.

The main aquaculture producers of the world are China (67\%), India (6\%), Viet Nam (3\%), Indonesia, Thailand, Bangladesh, Japan, Chile, and Norway. Asia is by far the dominant producer. However, there are major producers in all continents, including Africa where Egypt produces almost 1 million tonnes from aquaculture per year.

Fig. 1 shows the share of world fisheries production destined for exports. Almost 40 percent of global production enters the international market, thus making fish a truly global commodity. Fish exports have been growing but the 50/50 share between developed and developing countries has remained fairly stable (Fig. 2). World fish trade is growing strongly, an additional 8 percent from 2006 figures, with a value of USD 93 billion for 2007 (Fig. 2). Net export revenues earned by developing countries from fish exports are crucial to the economy of many developing countries amounting to a total USD 25 billion per year for this group of countries. These figures are significantly higher than those for other agricultural commodities such as coffee, rubber, cocoa, bananas, meat, tea, etc.

China is now the single, main exporter having overtaken Norway and Thailand a few years back. The USA and Canada are also major exporters. The rising role of Viet Nam as a producer and exporter is noteworthy. If the European Union (EU) is considered one group, its combined exports would be the largest although much of what is exported from one EU country is imported by another EU neighbor (Fig. 3). It was noted earlier that close to 50 percent of fish exports come from developing countries. When looking at imports we see a much higher concentration among a few countries, with three markets taking 71 percent of the total (EU, Japan, USA). This share though is declining as other developing countries are importing more than before. However, the EU share is somewhat overstated as it includes intra-EU trade as well. Excluding intra-EU trade, its share of imports becomes about 23 percent, which is still the highest among the three biggest markets.

The ornamental or aquarium fish sector is an important activity in many countries, involving more than 


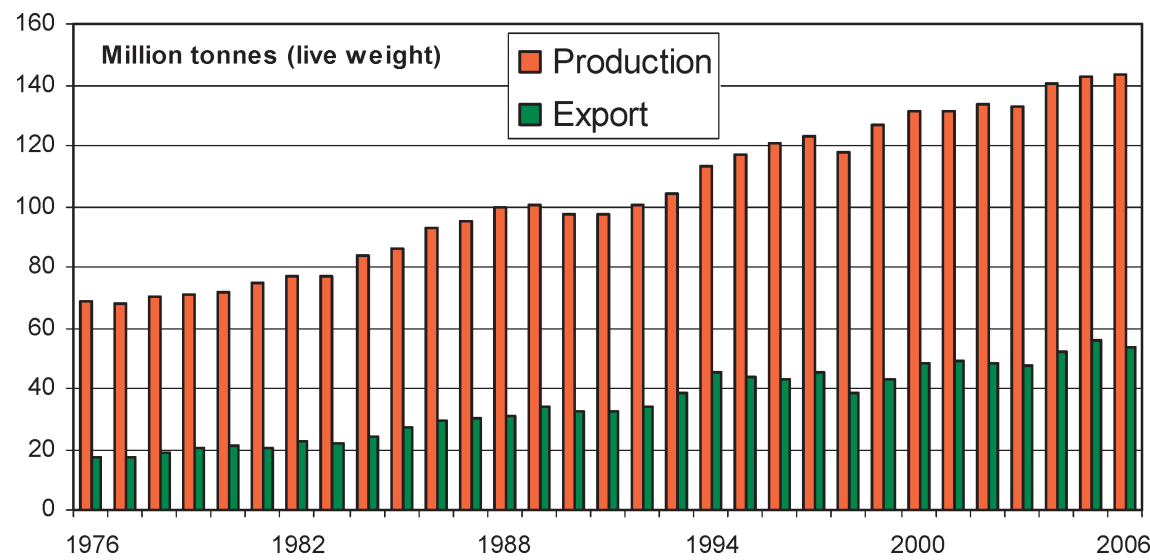

Fig. 1. Share of world fisheries production destined for export (FAO, 2007b).

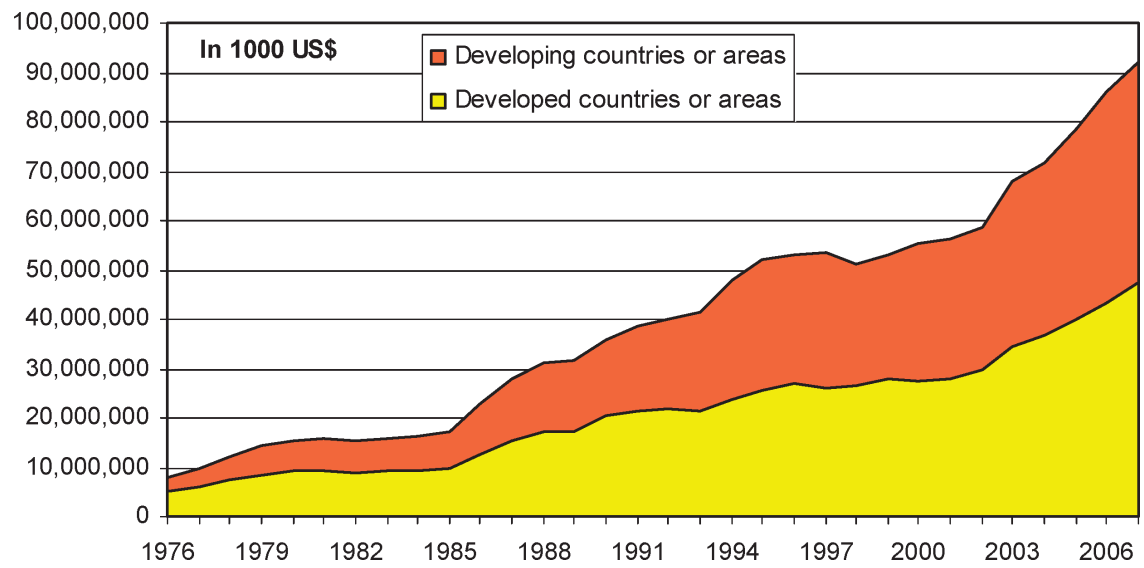

Fig. 2. World fish trade: export value (in 1,000 USD) (FAO, 2007b).

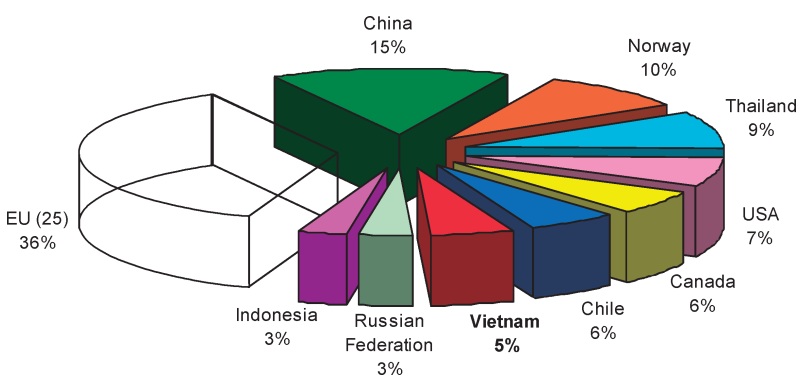

Fig. 3. Main fish exporters for 2007 by value (FAO, 2007b).

2,000 species and hundreds of millions of fish annually. For example, in 2001 Malaysia has produced 338 million freshwater aquatic ornamentals of which 293 million belong to 90 species with a value of USD 21 million. The sector is highly unregulated; it involves a high volume of transshipments that mask the origin of individual shipments. Due to the complexity of the trade, guarantees of the health status become difficult, if not impossible (Arthur et al., 2008). The sector has not received the detailed attention it deserves compared to food fish trade ${ }^{2}$.

Globalization and increasing trade flows bring economic benefits to many participants but also represent new challenges to the sustainable development of the fisheries and aquaculture sector. Some aspects of biosecurity could also potentially become major threats with important challenges to developed and developing countries alike. From civil society and by many consumers groups, concerns are raised about a number of issues, including whether fish farming is safe, about environmental impacts and workers' rights, the use of antibiotics and about safety and quality issues.

\section{Biosecurity, risk analysis and aquaculture}

FAO defines biosecurity as a strategic and integrated approach that encompasses both policy and regulatory frameworks (FAO, 2007c). Biosecurity is aimed at analysing and managing the risks of sectors dealing with food safety, animal life and health, plant life

\footnotetext{
2 FAO Globefish Research Programme Report Volume 67, The Ornamental Fish Market, October 2000.
} 
and health and the environment. In general terms, the current increased attention on biosecurity can be traced to ongoing developments such as increasing volume and diversity of trade, changing agricultural practice and climate, changing human and behavioral ecology, more sophisticated detection and management of hazards and greater demands for public health and environmental protection. What is then the relationship of risk analysis to biosecurity? In the global climate of free trade, risk analysis is at the heart of modern approaches to biosecurity; it is a unifying concept across different biosecurity sectors. It has become an essential decision-making tool to achieve the goals of protecting human, animal, and plant health and biodiversity. National Competent Authorities (CA) are now bound by international agreements to utilize risk analysis - thus putting new responsibilities and accountabilities to the CA.

In aquaculture, biosecurity is a collective term that refers to the concept of applying appropriate measures (e.g. proactive disease risk analysis) to reduce the probability of a biological organism or agent spreading to an individual, population or ecosystem, and to mitigate the adverse impact that may result (Subasinghe and Bondad-Reantaso, 2006). This analysis is done in a way that incorporates the best information available on aspects of husbandry, epidemiology and good science. In aquaculture, the drivers of risk analysis include resource protection, food security, trade, consumer preference for high quality and safe products, production profitability as well as other investment and development objectives.

The World Trade Organization's Agreement on Sanitary and Phytosanitary Measures (WTO's SPS Agreement) emphasizes the need to apply risk analysis as basis for taking any SPS measures.

\section{International treaties and guidelines in the international trade of aquatic animals}

The WTO's SPS Agreement is the main regulatory instrument governing biosecurity. The three main international standards are: 1) the Codex Alimentarius Commission (of $\mathrm{FAO} / \mathrm{WHO}$ ) which is concerned with food safety, 2) the World Organization for Animal Health or Office International des Epizooties (OIE) who is concerned with animal including aquatic animal) life and health; and 3) the International Plant Protection Convention (IPPC) which is concerned with plant life and health.

The international trade in aquatic animals are governed by different obligatory international treaties/ agreements and other voluntary guidelines. Examples of binding international agreements are that of WTO's SPS Agreement (WTO, 1994), the Convention on Biological Diversity (CBD, 1992) and the Convention on
International Trade of Endangered Species (CITES). Examples of voluntary agreements/guidelines include that of the International Convention for the Exploration of the Seas (ICES, 2005), the European Inland Fisheries Advisory Commission (Turner, 1988) and a number of FAO guidelines. Often, however, voluntary international guidelines are incorporated into national legislation and thus become mandatory at the national level.

With respect to animal health of the SPS Agreement, the World Animal Health Organization or OIE is the agency responsible for setting standards. With reference to aquatic animal health, the OIE has two major publications, e.g. the Aquatic Animal Health Code (OIE, 2007) and the Diagnostic Tests for Aquatic Animal Diseases. It also has an Aquatic Animal Health Standards Commission and a number of reference laboratories for specific aquatic animal diseases. Compliance to these standards are obligatory to the more than 158 members of OIE. OIE's list of diseases of aquatic animals are those deemed important to international trade.

EU's animal health strategy (2007-2013) is embedded in the principle that "prevention is better than cure". The EU aquaculture is worth more than Euro 25 billion in 2004, but financial losses due to diseases were estimated at 20 percent of the production value (or about Euro 500 million).

There are also voluntary guidelines. FAO, for example, have published a number of technical guidelines (FAO, 2007d; FAO/NACA, 2000; FAO, 1995) to guide FAO member countries in the responsible conduct of aquaculture and health management for responsible movement of live aquatic animals.

The essential components of a biosecurity and national strategy framework, under the FAO guidelines, consist of these elements: policy, legislation and enforcement, risk analysis, pathogen list, information system, health certification and quarantine, surveillance and reporting, zoning, emergency preparedness, institutional structure, human resource development and regional and international cooperation.

National strategies on aquatic animal health are important tools as they contain the government's action plans at the short, medium- and long-term with respect to aquatic animal health management. Many countries are now in the process of implementing and/or developing national aquatic animal health strategies or its equivalent. Notable are those of Australia, Canada, the USA, Thailand, and Singapore (Amos, 2004; Bernoth et al., 2008; Bondad-Reantaso, 2004; Olivier, 2004; Kanchanakhan and Chinabut, 2004).

The FAO global guidelines also include guidance on health management at the farm level and specific elements include cluster management, better management practices, compliance with national legislation, certification, on-farm disease prevention, surveillance and reporting of disease outbreaks, emergency prepared- 
ness and information sharing and farmer education.

Examples of aquatic animal health risks related to the international movement of live aquatic animals include the emergence of new pathogens due to the rapid development of aquaculture, limitations in control options for aquatic animal diseases, occurrence of multifactorial disease syndromes, frequent sub-clinical infections in aquatic animals, undomesticated status of aquatic animals and little information available on biological requirements and health status, and others.

\section{Transboundary aquatic animal diseases and pathways for their spread: three examples}

Looking at some of the impacts of transboundary aquatic animal diseases and economic investments on aquatic animal health, although data is a very grey area in the literature, the information is becoming more available due to the rising awareness on aquatic animal health issues (Bondad-Reantaso et al., 2005). National estimates of production losses for example can go from a low of USD 17.5 million due to white spot disease (WSD, =PAV) of shrimp in India in 1994 to as high as USD 650 million for yellowhead disease of shrimp in Thailand in the same year; to a global estimate of USD 3019 million for shrimp diseases. Norway and Canada's annual losses due to infectious salmon anemia (ISA) were USD 11 million and USD 14 million, respectively. For disease control programmes, the USA spends USD 8.3 million for ISA and USD 11.7 million for spring viremia of carp (SVC). For generic disease control programmes, Canada spends USD 34 million, China spends USD 37 million and Norway spends about USD 4 million. For research, Norway spends USD 50 million, Thailand USD 5 million and China USD 6 million. Australia spent USD 2 million for 4 years of development and initial implementation of Aquaplan, while the USA spent USD 375,000 for the initial development of its strategy. With respect to market and research and development costs for aquatic animal health products, the value is staggering with about USD 938 million worth of market size for products such as biologicals, antibiotics, antiparasitics, etc. with R\&D investment costs worth USD 48 million. The stakes are high.

Three examples are provided below which demonstrate different goals for aquatic animal movements involving different pathways - and thus, present different levels of risks of pathogen transfers.

Example 1: Koi herpesvirus (KHV) in Indonesia: national spread of KHV from ornamental fish to cultured and wild stocks. $\mathrm{KHV}$ is a good example of a disease which originated from an ornamental fish and which spread to cultured and eventually wild fish stocks (Bondad-Reantaso et al., 2007) and another strong evidence of ornamental fish being a significant vector of viral diseases alongside with spring viremia of carp virus and ranaviruses. As previously mentioned, ornamental fish trade is unregulated. In the context of trade - there may be a need to change the current thinking as to how to deal with ornamentals. An effective or meaningful import health requirements may be strictly required. A retrospective analysis of the KHV history in Indonesia shows that the origin of the infection was from a koi carp imported from China through Hong Kong; the first major outbreak of KHV among koi carps in March 2002 occurred in Blitar, the center for koi carp farming in Indonesia, how it spread to cultured common carp in March-April in Subang, the center for common carp culture in the country and how it quickly spread to a reservoir affecting both cultured and wild carps. Despite a ministerial ban restricting live fish movement, this did not prevent the disease from spreading to another island. Since the major outbreak in Indonesia in 2002, the following year, KHV appeared in Japan and a number of other Asian countries.

Example 2: Global spread of white spot syndrome virus (WSSV, =PRDV) in shrimp. A second example is that of WSSV, considered as the most serious pathogen of cultivated shrimp in the world. Recorded shrimp viral epizootics show the range and distance that aquatic animals can travel alongside the movement of their hosts - the major pathway being movement of infected post-larvae, fingerlings and broodstock. At present there are more than 20 shrimp producing countries affected, the latest to be hit was Brazil and Iran in 2005 (http:// www.oie.int/wahis/public.php?page=disease_immediate_ summary\&selected_year=2005; Cavalli et al., 2008).

Example 3: Epizootic ulcerative syndrome (EUS), international spread and its emergence in southern Africa 10 years after the last major outbreak in Asia. EUS was first described in Japan in 1971 as a fungal infection and was called mycotic granulomatosis (MG). In Australia, a similar outbreak called red spot disease (RSD) occurred in 1972. Since 1978 an ulcerative disease affecting Atlantic menhaden, Brevoortia tyrannus, was called ulcerative menhaden disease (UM) in the USA. In 1985, major finfish disease outbreaks occurred in Asia and in 1986 it was called epizootic ulcerative syndrome or EUS. In 2002, a group of MG, RSD, UM and EUS experts from Japan, Australia, USA, India, the Philippines and Thailand met and concluded that the above diseases are the same and proposed a new name - epizootic granulomatous aphanomycosis (EGA) or ulcerative aphanomycosis (Baldock et al., 2005). The last major outbreak of EUS in Asia was in Pakistan in the late 1990s.

Fast forward, in December 2006, there were reports of a serious finfish disease occurring in the Chobe-Zambezi River in southern Africa. An international disease investigation task force organized by $\mathrm{FAO}$ in 2007, confirmed that the disease in question is EUS (FAO, 2009). While the origin of EUS in southern 


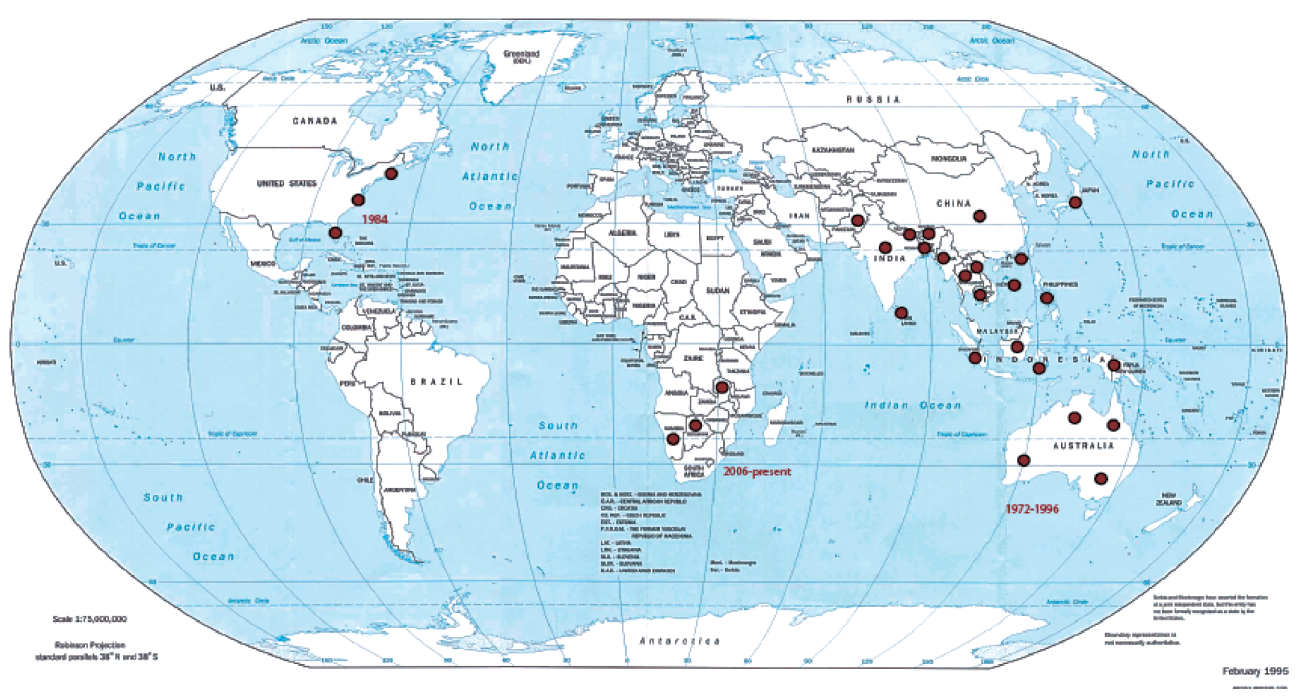

Fig. 4. Current global distribution of epizootic ulcerative syndrome.

Africa is still a big question, it demonstrated biosecurity lapses in the region. Ongoing efforts to assist in dealing with this new incursion in Africa of an old disease include an active targeted surveillance of EUS and assisting in building capacity on aquatic biosecurity for the region. FAO is currently working closely with OIE and NEPAD to achieve these within the framework of FAO's Special Programme for Aquaculture Development in Africa. Fig. 4 shows the current distribution of EUS since it was first reported in Japan in 1971, with three additional countries (Botswana, Namibia and Zambia) positive for EUS, two countries suspected (Angola and Zimbabwe) and more than 20 African freshwater fish species now susceptible to EUS (FAO, 2009).

Additional examples of other pathways (i.e. live food or fresh food) demonstrating the risks of disease transfer are mentioned below. The larval cestode Callotetrarhynchus nipponica is an example of a parasite problem of yellowtail Seriola quinqueradiata associated with feeding with raw anchovy Engraulis japonica (Ogawa, 1996). The use of non-native food stocks such as live, fresh or frozen materials represents the "silent sleeper" of aquaculture-related invasions; these also represents a poorly managed pathway of pathogen importation that can affect both cultured and wild stocks such as the case of pilchard mortalities in Australia and New Zealand (Campbell and Hewitt, 2008). Baitfish of the species Sardinops sagax and a mix of bycatch species imported from California, Peru, Chile and Japan, without quarantine and on a scale of more than 16,000 tonnes per annum for feeding sea-caged blue fin tuna in Southern Australia is near where epizootics began. It was hypothesized that this is the most likely source of the introduction of herpesvirus in Australian waters.

In the context of aquatic animal health, pathogen risk analysis (also termed as import risk analysis) is a structured process for analyzing the disease risks associated with the international and domestic movements of live aquatic animals and their products. The late Dr Chris Baldock, a world renowned epidemiologist drew up a risk hierarchy indicating that the level of risk is higher among live adult animals as compared to those of live young animals, eggs and sperms and fresh and processed products.

It is important to understand the pathways for pathogen occurrence and spread (Bondad-Reantaso and Arthur, 2008). Pathway analysis is an important step in the risk analysis process. It provides a logical process by which the critical risk steps (events) leading to pathogen introduction and establishment in an importing country can be identified and it allows estimation of the probability of each event occurring and being completed. The effectiveness of risk management measures can be determined when incorporated into the pathway analysis.

\section{Managing the risks}

Reducing the risks from aquatic animal diseases through effective biosecurity can be achieved through the following: 1) improving responsibility in transboundary movement of live aquatic animals and their products through effective national strategies and national policy and regulatory frameworks as basis for enhancing compliance with regional and international treaties and instruments, 2) applying risk analysis to support timely assessment of the threat from new or expanding species, 3) surveillance programme and diagnostic services to detect and identify the emergence and spread of diseases, 4) emergency preparedness through rapid and timely response to reduce potential catastrophic conse- 
quences of disease incursion, 5) empowering and educating farmers with information and tools such as better management practices, simple and practical biosecurity measures at the farm level, organization into clusters, 6) generating research and information that will support biosecurity assessments, early warning, 7) building capacity at all levels, 8) enhancing aquatic animal welfare as a prerequisite to aquatic animal health, and 9) building partnerships and enhancing regional and international cooperation.

Risk analysis is an important decision-making tool. However, it is only one of a large number of components of an aquatic animal health strategy. It cannot function effectively unless the other components have been developed and the means to implement them are in place. Despite the best risk analysis and risk mitigation measures, serious pathogens will be introduced and cause major disease problems. This is due to limitations in diagnostic techniques, existence of cryptic pathogens and ability of benign organisms to become pathogenic when introduced to new hosts and new environments. Efforts should therefore be focused on prevention and maintaining a healthy aquatic production.

Biosecurity will be an important challenge to sustainable aquaculture development. Biosecurity safeguards animal health, protects biodiversity, promotes environmental sustainability and enhances food safety. Biosecurity can also stimulate increased market supply and private investments as it enables farmers to produce healthy products which can be highly competitive in the market and makes a country a responsible trading partner.

Farmers have a critical role to play. Farmer education is also essential. An informed farmer will not throw dead fish into the open water system, they will not trade diseased fish and will not discharge contaminated water; and they will use veterinary drugs in a responsible and prudent way. Empowering farmers to manage risks will be one good way to manage aquatic animal health. This can be achieved through cluster management especially of the thousands of small-scale farmers who are primary producers in aquaculture. They need tools and information at the pond/farm level such as situation specific better management practices (BMPs) including good health management and biosecurity practices.

The risks of transboundary aquatic disease epizootics can be reduced through effective prevention and control measures which should necessarily be complemented with improved diagnostic and extension services, educational programmes and other capacity building activities for farmers and other seafood producers. It is important to ensure that operational capability at the national level is in place and prepared to effectively respond to disease emergencies, and such a national approach be supported by a well- planned regional strategy.

\section{Conclusions}

The importance of aquaculture is undoubtedly recognized and the sector is a major contributor to food security, nutritional well-being, poverty reduction and economic development. The further development of aquaculture therefore brings new challenges to aquatic animal health.

International trade of aquatic animals and their products have been recognized as a significant pathway for the introduction of TAADs. Improving biosecurity and reducing the risks of TAADs are therefore essential to sustainable aquaculture development.

We would like to conclude this paper using a popular adage in the western culture which states that "...whatever can go wrong will go wrong, in any given situation, if you give them a chance....". And with respect to health management, the old adage "an ounce of prevention is worth a pound of cure", an expression which means that it is better to try to avoid problems in the first place, rather than trying to fix them once they arise, is still a very important concept which needs to be applied to sustainable aquaculture development. Fish pathology and biosecurity are indispensable and are absolute necessities in sustainable aquaculture.

\section{Acknowledgements}

The first author, M.G. Bondad-Reantaso, would like to thank the organizers of the 5th International Symposium of the Japanese Society for Fish Pathology (JSFP2008) for the invitation as Keynote Speaker and travel support to participate in this event. FAO is also acknowledged for permission to attend this conference on official time.

\section{References}

Amos, K. (2004): National aquatic animal health plan for the United States of America, In "Capacity and awareness building on import risk analysis for aquatic animals" (ed. by J. R. Arthur and M. G. Bondad-Reantaso). Proceedings of the workshops held 1-6 April 2000 in Bangkok, Thailand and 12-17 August 2002 in Mazatlan, Mexico, APEC FWG 01/2002, NACA, Bangkok, pp. 147-150.

Arthur, J. R., C. F. Baldock, M. G. Bondad-Reantaso, R. Perera, B. Ponia and C. J. Rodgers (2008): Pathogen risk analysis for biosecurity and the management of aquatic animal movements. In "Diseases in Asian aquaculture VI" (ed. by M. G. Bondad-Reantaso, C. V. Mohan, M. Crumlish and R. P. Subasinghe). Fish Health Section, Asian Fisheries Society, Manila, pp. 21-52.

Baldock, C. (2002): Health management issues in the rural livestock sector: useful lessons for consideration when formulating programmes on health management in rural, small-scale aquaculture for livelihood. In "Primary 
aquatic animal health care in rural, small-scale aquaculture development" (ed. by J. R. Arthur, M. J. Phillips, R. P. Subasinghe, M. B. Reantaso and I. H. MacRae). FAO Fisheries and Aquaculture Technical Paper No. 406, FAO, Rome, pp. 7-19.

Baldock, F. C., V. Blazer, R. B. Callinan, K. Hatai, I. Karunasagar, C. V. Mohan and M. G. Bondad-Reantaso (2005): Outcomes of a short expert consultation on epizootic ulcerative syndrome (EUS): re-examination of causal factors, case definition and nomenclature. In "Diseases in Asian aquaculture V" (ed. by P. J. Walker, R. G. Lester and M. G. Bondad-Reantaso). Fish Health Section, Asian Fisheries Society, Manila, pp. 555-558.

Bernoth, E.-M., I. Ernst and B. Wright (2008): National aquatic animal health plans-the Australian experience, In "Changing trends in managing aquatic animal disease emergencies" (ed. by E.-M. Bernoth). Rev. Sci. Tech. Off. Int. Epiz., 27, 71-88.

Bondad-Reantaso, M. G. (2004): Trans-boundary aquatic animal diseases/pathogens, In "Capacity and awareness building on import risk analysis for aquatic animals" (ed. by J. R. Arthur and M. G. Bondad-Reantaso). Proceedings of the workshops held 1-6 April 2002 in Bangkok, Thailand and 12-17 August 2002 in Mazatlan, Mexico. APEC FWG 01/2002, NACA, Bangkok, pp. 9-22.

Bondad-Reantaso, M. G. and J. R. Arthur (2008): Pathogen risk analysis for aquaculture production. In "Understanding and applying risk analysis in aquaculture" (ed. by M. G. Bondad-Reantaso, J. R. Arthur and R. P. Subasinghe). FAO Fisheries and Aquaculture Technical Paper No. 519, FAO, Rome, pp. 27-46.

Bondad-Reantaso, M. G., A. Sunarto and R. P. Subasinghe (2007): Managing the koi herpesvirus disease outbreak in Indonesia and the lessons learned. In "The OIE Global Conference on Aquatic Animal Health" (ed. by B. Dodet and the OIE Scientific and Technical Department), Developments in Biologicals, 129, 21-28.

Bondad-Reantaso, M. G., R. P. Subasinghe, J. R. Arthur, K. Ogawa, S. Chinabut, R. Adlard, Z. Tan and M. Shariff (2005): Disease and health management in Asian aquaculture. Vet. Parasitol., 132, 249-272.

Campbell, M. L. and C. Hewitt (2008): Introduced marine species risk assessment-aquaculture. In "Understanding and applying risk analysis in aquaculture" (ed. by M. G. Bondad-Reantaso, J. R. Arthur and R. P. Subasinghe). FAO Fisheries and Aquaculture Technical Paper No. 519, FAO, Rome, pp. 121-134.

CBD. 1992. Convention on Biological Diversity. 5 June 1992, $29 \mathrm{p}$.

Cavalli, L. S., L. F. Marins, S. Netto and P. C. Abreu (2008): Evaluation of white spot syndrome virus (WSSV) in wild shrimp after a major outbreak in shrimp farms at Laguna, Southern Brazil. Atlantica Rio Grande, 30, 45-52.

FAO (1995): Code of conduct for responsible fisheries. FAO, Rome, $41 \mathrm{p}$.

FAO (2007a): State of the world aquaculture 2006. FAO Fisheries Technical Paper No. 500. FAO, Rome, Italy, 134 p.

FAO (2007b): Fishstat+ database. FAO, Rome. http://www. fao.org/fi/statist/FISOFT/FISHPLUS.asp.
FAO (2007c): FAO Biosecurity Toolkit. FAO, Rome, 128 p.

FAO (2007d): Aquaculture development 2. Health management for responsible movement of live aquatic animals. FAO Technical Guidelines for Responsible Fisheries. No. 5, Suppl. 2, FAO, Rome, $31 \mathrm{p}$.

FAO (2009): Report of the International Emergency Disease Investigation Task Force on a Serious Finfish Disease in Southern Africa, 18-26 May 2007. FAO, Rome, 70 p.

FAO/NACA (2000): The Asia regional technical guidelines on health management for responsible movement of live aquatic animals and the Beijing consensus and implementation strategy. FAO Fisheries Technical Paper No. 402, $\mathrm{FAO}$, Rome, $53 \mathrm{p}$.

ICES (2005): ICES Code of Practice on the Introductions and Transfers of Marine Organisms 2005. International Council for the Exploration of the Sea, Copenhagen, $30 \mathrm{p}$.

Israngkura, A. and S. Sae-Hae (2002): A review of the economic impacts of aquatic animal diseases. In "Primary aquatic animal health care in rural, small-scale, aquaculture development" (ed. by J. R. Arthur, M. J. Phillips, R. P. Subasinghe, M. B. Reantaso and I. H. MacRae). FAO Fisheries and Aquaculture Technical Paper No. 406, FAO, Rome, pp. 253-286.

Kanchanakhan, S. and S. Chinabut (2004): Strategies for aquatic animal health management in Thailand. In "Capacity and awareness building on import risk analysis for aquatic animals" (ed. by J. R. Arthur and M. G. BondadReantaso). Proceedings of the workshops held 1-6 April 2000 in Bangkok, Thailand and 12-17 August 2002 in Mazatlan, Mexico, APEC FWG 01/2002, NACA, Bangkok, pp. 139-141.

Ogawa, K. (1996): Marine parasitology with special reference to Japanese fisheries and mariculture. Vet. Parasitol., 64, 95-105.

OIE (2007): OIE International Aquatic Animal Health Code, 10th Ed. Office International des Epizooties, Paris, 238 p.

Olivier, G. (2004): Canada's national aquatic animal health program. In "Capacity and awareness building on import risk analysis for aquatic animals" (ed. by J. R. Arthur and M. G. Bondad-Reantaso). Proceedings of the workshops held 1-6 April 2000 in Bangkok, Thailand and 12-17 August 2002 in Mazatlan, Mexico, APEC FWG 01/2002, NACA, Bangkok, pp. 115-117.

Subasinghe, R. P. and M. G. Bondad-Reantaso (2006): Biosecurity in aquaculture: International Agreements and Instruments, their Compliance, Prospects and Challenges for Developing Countries. In "Aquaculture Biosecurity: Prevention, Control and Eradication of Aquatic Animal Disease" (ed. by A. D. Scarfe, C-S. Lee and P. O' Bryen), Blackwell Publishing, Hawaii. pp. 9-16.

Turner, G. E. (1988): Codes of practice and manual of procedures for consideration of introductions and transfers of marine and freshwater organisms. EIFAC/CECPI Occasional paper No. 23, FAO, Rome, 44p.

WTO (1994): Agreement on the Application of Sanitary and Phytosanitary Measures. In "The results of the Uruguay Round of multilateral trade negotiations: the legal texts, General Agreement on Tariff and Trade (GATT)", World Trade Organization, Geneva, pp. 69-84. 